\title{
Effectiveness of manganese nanoparticles in the treatment of spring triticale seeds
}

\author{
Olga Vyushina*
}

Tyumen Scientific Center of the Siberian Branch of the Russian Academy of Sciences, 86 Malygina St., 625026 Tyumen, Russia

\begin{abstract}
In this work we studied the effect of finished preparative forms with manganese nanoparticles (monohydrate sulfate) with different contents and inclusion of stabilizers and solution modifiers on the growth and development of spring triticale plants in the first phases of ontogenesis. A positive effect of manganese on the increase of seed germination energy and germination of spring triticale at the dosage of $\mathrm{Mn} 20 \mathrm{mg} / \mathrm{g}+(\mathrm{PVP})$, with the drug consumption rate of $5 \mathrm{ml} / \mathrm{t}$, was found. In this variant, both manganese and polyvinylpyrrolidone (PVP) solution stabilizer are determined to be positive. The inclusion of collagen hydrolysate (GC) and $\mathrm{Ag}-\mathrm{K}$ modifier in the combination of the stabilizer solution, where the $\mathrm{Mn}$ content is $10 \mathrm{mg} / \mathrm{g}$, negatively affected and reduced the germination energy by $13-17 \%$ compared to the control variant. Increasing the manganese content in the samples up to $20 \mathrm{mg} / \mathrm{g}$ levels out the negative effect of $\mathrm{Ag}-\mathrm{K}$ modifier on seed germination. A positive effect within 7 days in most variants, both on the length of the sprout and on its weight was traced in the application of manganese with its content in the samples of $20 \mathrm{mg} / \mathrm{g}$ with a rate of $1 \mathrm{ml} / \mathrm{t}$.
\end{abstract}

\section{Introduction}

Micronutrients are found in plants in small amounts. Nevertheless, they play a primary role in all life processes. Lack of trace elements such as sulfur, magnesium, copper and manganese, as well as molybdenum and zinc causes disruption of carbohydrate metabolism, synthesis of protein substances, reduces plant resistance to diseases. Their use in the cultivation of grain crops is one of the factors that increase yields and improve product quality. The need of crops in micronutrients is increased during their cultivation by intensive technologies, as well as in adverse environmental conditions [1-3].

The most effective treatment of seeds by fungicides with the addition of various preparations stimulating germination and plant development [4]. Recently, such a form of compounds as nanocrystalline metal powders have been widely used as microfertilizers [5, $6]$.

Manganese $(\mathrm{Mn})$ is an element vital to all living organisms. On average, its amount in plants is $0.001 \%$. It is necessary for normal photosynthesis, contributing to the increase of chlorophyll in leaves, synthesis of sugars and ascorbic acid (vitamin C). With a lack of

\footnotetext{
${ }^{*}$ Corresponding author: vyushina63@mail
} 
manganese in plants, the ratio of mineral nutrition elements is disturbed, which leads to spot chlorosis. Cereals deficient in manganese, are affected by gray spot disease [7]. One of the ways to use this micronutrient is seed treatment (powdering). Manganese sulfate (manganese sulfate), a powder containing manganese - a mechanical mixture of finely ground dry manganese sulfate and technical talc are used for seed pre-treatment [8].

The aim of the study was to establish the positive effect of different manganese nanoforms (monohydrate sulfate) on important sowing parameters (energy, germination) and the initial growth of spring triticale.

\section{Materials and Methods}

The studies were performed under laboratory conditions in Scientific Research Institute of Agriculture for Northern Trans-Ural Region - Branch of Federal State Institutions Federal Research Centre Tyumen Scientific Centre of Siberian Branch of the Russian Academy of Sciences в 2020 г. The object of the research is manganese nanoparticles (monohydrate sulfate). Seeds of spring triticale - variety Ukro were taken for the experiment.

This is one of the promising cereal crops characterized by high productivity potential and grain quality, resistance to adverse soil and climatic conditions and diseases. Triticale is used as forage, food and fodder crops [9, 10].

Six nano-samples of manganese (monohydrate sulfate) were used in the experiment:

1. Mn 1- Manganese content $10 \mathrm{mg} / \mathrm{g}$. Nano-dispersion stabilizer PVP (polyvinylpyrrolidone, 20\%);

2. Mn 1- Manganese content $20 \mathrm{mg} / \mathrm{g}$. Nano-dispersion stabilizer PVP (polyvinylpyrrolidone, 20\%);

3. Mn 1- Manganese content $20 \mathrm{mg} / \mathrm{g}$. Nano-dispersion stabilizer PVP (polyvinylpyrrolidone, 20\%); $\mathrm{Ag}-\mathrm{K}$ modifier at a concentration of $0.15 \mathrm{mg} / \mathrm{g}$.

4. Mn 4 - Manganese content $10 \mathrm{mg} / \mathrm{g}$. Nano-dispersion stabilizer PVP (polyvinylpyrrolidone, 20\%) $+\mathrm{Ag}-\mathrm{K}$ modifier at a concentration of $0.15 \mathrm{mg} / \mathrm{g}$.

5. Mn 5 - The content of manganese is $10 \mathrm{mg} / \mathrm{g}$. Stabilizer nanodispersity collagen hydrolyzate $15 \%$.

6. Mn 6 - The content of manganese is $10 \mathrm{mg} / \mathrm{g}$. Stabilizer nanodispersity collagen hydrolyzate $15 \%$, modifier Ag-K at a concentration of $0.15 \mathrm{mg} / \mathrm{g}$.

7. Control $-\mathrm{H}_{2} \mathrm{O}$ (distilled water)

Consumption rate of the preparation in the experiment is from $1 \mathrm{ml} / \mathrm{t}$ to $10 \mathrm{ml} / \mathrm{t}$.

Treatment with the preparation was carried out at the rate of $100 \mathrm{~g}$ of seeds with exposure of 1 hour before putting them into Petri dishes for germination in four replications - for energy and germination. Energy was counted on the 3rd day, germination on the 7th day. The samples were taken in accordance with GOST 12038-84. Seeds of agricultural crops. Methods of analysis [11]. Evaluation of the influence of different forms of manganese nanoformson peculiarities of seedlings growth was carried out by biometric analysis of aboveground part and root system during germination in rolls.

\section{Results and discussion}

When analyzing the effect of norms and combinations of Mn nanoparticles in different dosages with the inclusion of stabilizers (PVP) polyvinylpyrrolidone, (GC) collagen hydrolysate in the solution and the use of Ag-K solution modifier for pre-sowing treatment of seeds, the following results on the effect on germination energy and germination rate of spring triticale seeds were obtained. Positive effect on germination energy, was shown by variations with the dosage of $\mathrm{Mn} 10 \mathrm{mg} / \mathrm{g}+(\mathrm{PVP})$, with the application rate on seeds - 10 
$\mathrm{ml} / \mathrm{t}$, where the increase in energy was $+2.0 \%$. But a greater positive effect on this indicator was obtained with a dosage of Mn $20 \mathrm{mg} / \mathrm{g}+$ (PVP), where an increase of $4.0 \%$ was observed at the rate of $5 \mathrm{ml} / \mathrm{t}$. This is the highest reliable indicator of triticale seed germination energy of all selected combinations of Mn. Application of variant № 6, where the amount of Mn $10 \mathrm{mg} / \mathrm{g}$ with the inclusion of stabilizer (GC) and modifier Ag-K, on the contrary, affected negatively and reduced germination energy by $13-17 \%$. In these variants, it is possible that the effect of GC stabilizer and modifier is inverse and inhibits the growth functions of the seed. The negative effect of Ag-K modifier on energy and germination of triticale, may be due to its increased viscosity, which makes it difficult for manganese penetration into the seed and germination of the seed germ. However, in variant № 3 with manganese content of $20 \mathrm{mg} / \mathrm{g}$, regardless of the rate of consumption of the preparation, the negative effect of Ag-K modifier, was not observed. The energy index was at the level with the control, or slightly higher. That is, increasing manganese content in the samples levels out the negative effect of $\mathrm{Ag}-\mathrm{K}$ modifier on seed germination. Of the selected options, a combination of Mn dosage $20 \mathrm{mg} / \mathrm{g}+$ (PVP) $20 \%$ with the application rate on seeds from 5 $\mathrm{ml} / \mathrm{t}$ showed a positive effect on germination energy. With increasing germination energy, germination rate increased accordingly (Table 1).

Table 1. Effect of manganese (monohydrate sulfate) on energy and germination of spring triticale seeds

\begin{tabular}{|c|c|c|}
\hline Option & Energy & Germination \\
\hline No. 1 norm $1 \mathrm{ml} / \mathrm{t}$ & $96(+1,0)$ & $\mathbf{9 7}(+\mathbf{2 , 0})$ \\
\hline No. 1 norm $5 \mathrm{ml} / \mathrm{t}$ & $95(-)$ & $95(-)$ \\
\hline No. 1 norm $10 \mathrm{ml} / \mathrm{t}$ & $\mathbf{9 7}(\mathbf{+ 2 , 0 )}$ & $\mathbf{9 8}(+\mathbf{3 , 0})$ \\
\hline No. 2 norm $1 \mathrm{ml} / \mathrm{t}$ & $96(+1,0)$ & $96(+1,0)$ \\
\hline No. 2 norm $5 \mathrm{ml} / \mathrm{t}$ & $\mathbf{9 9}(\mathbf{+ 4 , 0 )}$ & $\mathbf{9 9}(+\mathbf{4 , 0})$ \\
\hline No. 3 norm $1 \mathrm{ml} / \mathrm{t}$ & $95(-)$ & $\mathbf{9 7}(+\mathbf{2 , 0})$ \\
\hline No. 3 norm $5 \mathrm{ml} / \mathrm{t}$ & $95(-)$ & $96(+1,0)$ \\
\hline No. 4 norm $1 \mathrm{ml} / \mathrm{t}$ & $94(-1,0)$ & $94(-1,0)$ \\
\hline No. 4 norm $5 \mathrm{ml} / \mathrm{t}$ & $93(-2,0)$ & $95(-)$ \\
\hline No. 5 norm $1 \mathrm{ml} / \mathrm{t}$ & $\mathbf{9 7}(\mathbf{2 , 0})$ & $\mathbf{9 7}(+\mathbf{2 , 0})$ \\
\hline No. 5 norm $5 \mathrm{ml} / \mathrm{t}$ & $95(-)$ & $96(+1,0)$ \\
\hline No. 6 norm $1 \mathrm{ml} / \mathrm{t}$ & $78(-17,0)$ & $83(-12,0)$ \\
\hline No. 6 norm $5 \mathrm{ml} / \mathrm{t}$ & $82(-13,0)$ & $83(-12,0)$ \\
\hline No. 7 control $(\mathrm{water})$ & 95 & 95 \\
\hline
\end{tabular}

The maximum increase in germination when using nanoparticles was observed in the sample number 2 with the rate of $5 \mathrm{ml} / \mathrm{t}-99 \%$, and it is equal to the germination energy in this variant. In other samples, the increase in germination relative to energy was either equal or had an increase of $1-5 \%$ in most at the rate of application on the seeds of $5 \mathrm{ml} / \mathrm{t}$. Relative to the control variant, an increase in seed germination was observed for variants № $1-\mathrm{Mn} 10 \mathrm{mg} / \mathrm{g}+(\mathrm{PVP})$ with a rate of $10 \mathrm{ml} / \mathrm{t}+3 \%$, № 2 - Mn $20 \mathrm{mg} / \mathrm{g}+(\mathrm{PVP})+4 \%$ with a rate of $5 \mathrm{ml} / \mathrm{t}$, a decrease in germination by $12 \%$ in variant № 6 with $\mathrm{Mn} 10 \mathrm{mg} / \mathrm{g}$ and presence of Ag-K modifier and at the control level № 4. In variants 1, 3, 5 there was a slight increase in germination by $1-2 \%$.

Analysis of development of spring triticale seedlings on day 7 of germination in filter paper rolls showed that in most of the studied variants, regardless of the application rate and combinations of Mn (sulfate monohydrate) preparation, a positive effect on the root length and sprouting of plants was traced.

Thus, the development of the root system was evaluated by the length of the main root, and the variants with a positive effect, contributing to an increase in root length by $6-34 \%$ stood out. The length changed (from the control $-13.6 \mathrm{~cm}$ ) increasing on average by $1.5-2$ $\mathrm{cm}$ and also decreasing in some variants, or was at the control level. There were marked out 
variants № 1 with the rate of $10 \mathrm{ml} /$ t, № 3, № 5. where greater effect on the root length was noted in the variant № 3 with the use of Mn $20 \mathrm{mg} / \mathrm{g}+(\mathrm{PVP}, \mathrm{Ag}-\mathrm{K})$, the increase was 22$34 \%$, in variants № 1, 2, 5 the root length increased by 5-10\%. In variants № 4, 6 there was a decrease in root length by $1-11 \%$ due to the effect of Ag-K modifier and reduced rate of $\mathrm{Mn}$ in the preparation. For most of the variants with the rate of $1 \mathrm{ml} / \mathrm{t}$ of the preparation the root length exceeded the control by $0.8-3.0 \mathrm{~cm}$. Increasing the rate to $5 \mathrm{ml} / \mathrm{t}$ led to a slight decrease in root length. Root mass excess in the leading variants № 1, 3,5 remained and amounted to $10-20 \%$, with a stable greatest influence on the variant № $3 \mathrm{Mn} 20 \mathrm{mg} / \mathrm{g}+$ (PVP, Ag-K) from the lower norm, to higher. Sprout length averaged 7.7-10.7 cm, in the control $9.2 \mathrm{~cm}$ and increased in some variants by 1-4 cm. Positive effect on the sprout length was exerted by variants № $1,2,3,5$, where the excess of the control was $16-40 \%$, the variant № $3 \mathrm{Mn} 20 \mathrm{mg} / \mathrm{g}+(\mathrm{PVP}, \mathrm{Ag}-\mathrm{K})$ at the rate of $1 \mathrm{ml} / \mathrm{t}$ stood out. The other variants and rates had no effect on sprout development, where the length was equal to the control. Sprout weight also confirmed the allocated variants by sprout length, where the increase in weight relative to control was $8-10 \%$ and its reduction by $3-20 \%$ in variants with a rate above $5 \mathrm{ml} / \mathrm{t}$ and the content of the stabilizer (GC), Ag-K modifier.

It should be noted the positive effect of $\mathrm{Mn} 20 \mathrm{mg} / \mathrm{g}$ with $\mathrm{Ag}-\mathrm{K}$ modifier in combination with nanodispersity stabilizer (PVP), at the rate of $1-5 \mathrm{ml} / \mathrm{t}$ on root development and at the rate of $1 \mathrm{ml} / \mathrm{t}$ on shoot growth. The content of manganese in nanoforms in the amount of 20 $\mathrm{mg} / \mathrm{g}$ with the addition of stabilizer (PVP) and modifier Ag-K had a positive effect on the activity of development of spring triticale plants in the first phases of ontogenesis. Due to activation of internal reserves of seed and growth functions of young plants, which further contributes to obtaining healthy powerful plants with higher resistance to adverse factors and the formation of a potentially possible crop yield (Table 2).

Table 2. Effect of manganese nanoparticles (sulfate monohydrate) on development parameters of spring triticale plants

\begin{tabular}{|c|c|c|c|c|}
\hline \multirow{2}{*}{ Option } & \multicolumn{2}{|c|}{ Length, cm } & \multicolumn{2}{|c|}{ Weight, g } \\
\hline & the root & sprout & the root & sprout \\
\hline No. 1 norm $1 \mathrm{ml} / \mathrm{t}$ & $14,4(+0,8)$ & $10,7(+1,5)$ & $5,29(+0,34)$ & $10,76(+0,85)$ \\
\hline No. 1 norm $5 \mathrm{ml} / \mathrm{t}$ & $11,1(-2,5)$ & $9,6(+0,4)$ & $4,09(-0,86)$ & $9,31(-0,6)$ \\
\hline No. 1 norm $10 \mathrm{ml} / \mathrm{t}$ & $15,0(+1,4)$ & $9,6(+0,4)$ & $5,95(+1,0)$ & $9,57(-0,34)$ \\
\hline No. 2 norm $1 \mathrm{ml} / \mathrm{t}$ & $14,5(+0,9)$ & $10,2(+1,0)$ & $4,40(-0,55)$ & $9,54(-0,37)$ \\
\hline No. 2 norm $5 \mathrm{ml} / \mathrm{t}$ & $14,0(+0,4)$ & $9,6(+0,4)$ & $5,00(+0,05)$ & $9,13(-0,78)$ \\
\hline No. 3 norm $1 \mathrm{ml} / \mathrm{t}$ & $16,6(+3,0)$ & $13,5(+4,3)$ & $6,04(+1,09)$ & $10,77(+0,86)$ \\
\hline No. 3 norm $5 \mathrm{ml} / \mathrm{t}$ & $18,3(+4,7)$ & $9,3(+0,1)$ & $6,15(+1,2)$ & $9,41(-0,5)$ \\
\hline No. 4 norm $1 \mathrm{ml} / \mathrm{t}$ & $13,1(-0,5)$ & $9,2(-)$ & $4,52(-0,43)$ & $8,92(-0,99)$ \\
\hline No. 4 norm $5 \mathrm{ml} / \mathrm{t}$ & $13,7(+0,1)$ & $9,0(-0,2)$ & $5,36(+0,41)$ & $10,68(+0,77)$ \\
\hline No. 5 norm $1 \mathrm{ml} / \mathrm{t}$ & $15,4(+1,8)$ & $11,1(+1,9)$ & $5,72(+0,77)$ & $10,37(+0,46)$ \\
\hline No. 5 norm $5 \mathrm{ml} / \mathrm{t}$ & $14,8(+1,2)$ & $8,7(-0,5)$ & $5,66(+0,71)$ & $8,66(-1,25)$ \\
\hline № 6 norm $1 \mathrm{ml} / \mathrm{t}$ & $13,4(-0,2)$ & $9,3(+0,1)$ & $4,47(-0,48)$ & $9,52(-0,39)$ \\
\hline No. 6 norm $5 \mathrm{ml} / \mathrm{t}$ & $12,1(-1,5)$ & $9,2(-)$ & $4,52(-0,43)$ & $7,76(-2,15)$ \\
\hline $\begin{array}{l}\text { No. } 7 \text { control } \\
\text { (water) }\end{array}$ & 13,6 & 9,2 & 4,95 & 9,91 \\
\hline
\end{tabular}

\section{Conclusions}

During the studies, it was found that manganese nanoparticles (monohydrate sulfate) in most cases have a stimulating effect, regardless of the rate of drug consumption, on the growth processes of spring triticale, stimulating, seed germination energy and germination, 
as well as a positive effect on the development and growth of roots and the above-ground part of triticale seedlings. The negative effect of manganese nanoparticles was traced only in the variants where nanodispersity stabilizer collagen hydrolysate and Ag-K modifier were present, but increasing manganese to $20 \mathrm{mg} / \mathrm{g}$ in the studied combinations in combination with stabilizer (PVP), contributed to an increase in energy and germination, root growth and seedlings. Therefore, we can conclude that manganese nanoparticles (monohydrate sulfate) can be used in the treatment of triticale seeds as growth stimulators.

\section{Acknowledgements}

Work performed under the state order № 121041600036-6.

\section{References}

1. Y.A. Azarenko, E.G. Pykhtareva, Electronic Scientific-Methodical Journal of the Omsk State Agrarian University, 3 (18) (2019) URL http://ejournal. omgau.ru/images/issues/2019/3/00759.pdf. - ISSN 2413-4066

2. Mikos-Szymanska, Marzena; Borowik, Mieczyslaw; Wyzinska, Marta; et al., 24th Annual International Scientific Conference on Research for Rural Development, Latvia Univ Life Sci \& Technologies, Jelgava, LATVIA (2018)

3. I. V. Obidina, G. I. Churilov, S. D. Polischuk, A. Yu. C. Gomozova, N. B. Rybin, L. E. Ampleeva, Vestnik NVSU, 2 (2020) https://doi.org/10.36906/2311-4444/20-2/06

4. O. Kolmykova, O. Cherkasov, Vestnik RGATU, 1 (37), 31-36 (2018)

5. A.M. Korotkova, S.V. Lebedev, F.G. Kayumrv, E.A. Sizova, Agricultural Biology, 52 (1), 172-182 (2017) http://doi: 10.15389/agrobiology.2017.1.172rus

6. Agata Święciło, Anna Krzepiłko, Sławomir Michałek and Marta Arczewska Agriculture, 10 (8), 312 (2020) doi.org/10.3390/agriculture10080312

7. Manganese (Mn) as a fertilizer for plants, application, necessary doses, recommendations, URL: https://zemlycraft.ru/udobreniya/marganecz-mn-kakudobrenie-dlya-rastenij-primenenie-neobhodimye-dozy-rekomendaczii (date of reference 21.04.2021).

8. Seedtreatment(seeddressing)// https://rosselhoscenter.com/files/users/95/\%D0\%98\%D0 $\% \mathrm{BD} \% \mathrm{D} 1 \% 84 \% \mathrm{D} 0 \% \mathrm{BE} \% \mathrm{D} 1 \% 80 \% \mathrm{D} 0 \% \mathrm{BC} \% \mathrm{D} 0 \% \mathrm{~B} 0 \% \mathrm{D} 1 \% 86 \% \mathrm{D} 0 \% \mathrm{~B} 8 \% \mathrm{D} 1 \% 8 \mathrm{~F}$ $\% \mathrm{D} 0 \% \mathrm{BE} \% \mathrm{D} 0 \% \mathrm{BF} \% \mathrm{D} 1 \% 80 \% \mathrm{D} 0 \% \mathrm{BE} \% \mathrm{D} 1 \% 82 \% \mathrm{D} 1 \% 80 \% \mathrm{D} 0 \% \mathrm{~B} 0 \% \mathrm{D} 0 \% \mathrm{~B} 2 \% \mathrm{D} \overline{0}$ $\% \mathrm{BB} \% \mathrm{D} 0 \% \mathrm{~B} 8 \% \mathrm{D} 0 \% \mathrm{~B} 2 \% \mathrm{D} 0 \% \mathrm{~B} 0 \% \mathrm{D} 0 \% \mathrm{BD} \% \mathrm{D} 0 \% \mathrm{~B} 8 \% \mathrm{D} 0 \% \mathrm{~B} 5 \%$ \% $1 \% 81 \% \mathrm{D} 0 \% \mathrm{~B}$ $5 \% \mathrm{D} 0 \% \mathrm{BC} \% \mathrm{D} 1 \% 8 \mathrm{~F} \_82 \mathrm{faf}$. (date of reference 22.04.2021 г.)

9. A.N. Kshnikatkina, A.N. Dolzhenko, Niva Povolzhya, 1 (54), 29-34 (2020) DOI 10.36461/NP.2020.54.1.005

10. S. Murtic, S. Muminovic, H. Civic, J. Chem. Bio. Phy. Sci. Sec. 7(1), 319-325 (2017)

11. GOST 12038-84. Seeds of agricultural crops, Methods of analysis. Sb. of State Standards, 47 (Moscow, Publishing house of standards, 2004) 